\title{
«Les animaux révélateurs des tensions politiques en République islamique d'Iran ». Études Rurales, 165-166, (janvier-juin 2003), pp. 123-132.
}

\section{Christian Bromberger}

\section{(2) OpenEdition}

Journals

Édition électronique

URL : http://journals.openedition.org/abstractairanica/1554

ISSN : 1961-960X

Éditeur :

CNRS (UMR 7528 Mondes iraniens et indiens), Éditions de l'IFRI

Édition imprimée

Date de publication : 15 mai 2005

ISSN : 0240-8910

Référence électronique

Christian Bromberger, « «Les animaux révélateurs des tensions politiques en République islamique d'Iran ». Études Rurales, 165-166, (janvier-juin 2003), pp. 123-132. », Abstracta Iranica [En ligne], Volume 26 | 2005, document 430, mis en ligne le 05 décembre 2005, consulté le 25 septembre 2020. URL : http://journals.openedition.org/abstractairanica/1554

Ce document a été généré automatiquement le 25 septembre 2020.

Tous droits réservés 


\section{« Les animaux révélateurs des tensions politiques en République islamique d'Iran ». Études Rurales, 165-166, (janvier-juin 2003), pp. 123-132.}

\section{Christian Bromberger}

La colombophilie, les combats de taureaux (toujours populaires au Gīlān et au Māzandarān), les courses de chevaux, l'équitation de loisir, le polo, la possession de chiens de compagnie (qui se répand dans les villes) ont suscité la réprobation ou la condamnation des autorités islamiques. Ces mesures répressives ou dissuasives ont été prises au nom de la šar'iyāt (interdisant les paris d'argent) et/ou de la lutte contre l'occidentalisation. Certaines ont fait l'objet d'adaptation (un fatvā de 1996 a assimilé les paris sur les courses de chevaux à des «anticipations sur les résultats »), d'autres ont été maintenues. Les attitudes des uns et des autres face à ces mesures traduisent leur position sur l'échiquier politique («conservateurs» rigoristes, jeunes «réformateurs » des classes aisées des villes prisant volontiers l'équitation et les animaux de compagnie, «nationalistes » soucieux du maintien des jeux et sports traditionnels). Ces controverses animalières sont, nous montre l'A. dans cet article original, de puissants révélateurs des débats qui traversent la société iranienne aujourd'hui. 
INDEX

nompropre Māzandarān, Gìlān

Keywords : šar'iyāt, fatvā, money bets, horse-races

Mots-clés : paris d'argent, courses de chevaux

\section{AUTEURS}

CHRISTIAN BROMBERGER

Université de Provence 